UDK 81'373.612-055-3

Izvorni znanstveni članak

Prihvaćeno za tisak: 10. rujna 2018.

https://doi.org/10.22210/suvlin.2018.086.03

\author{
Rusty Barrett \\ University of Kentucky \\ erbarrett@uky.edu
}

\title{
Speech play, gender play, and the verbal artistry of queer argots
}

\begin{abstract}
This paper presents a comparative study of argots (or secret varieties) used in communities marked by non-normative gender or sexuality. A comparison of nine argots based in different languages suggests that the development of each of these argots involves large amounts of speech play. A variety of patterns of speech play are analyzed, including cross-language play, play languages, morphological restructuring and innovation, and lexical substitutions within the local language. The importance of speech play in these communities is illustrated with the genre of mock translations in which familiar texts (such as Shakespeare or the Bible) are reproduced using argot. The results suggest that speech play and verbal artistry are important and understudied elements of queer cultures.
\end{abstract}

\section{Introduction}

This paper compares a number of distinct "secret" language varieties used in gender/sexual non-normative communities to examine which (if any) features might be shared across them. While there have been a number of studies of specific "queer argots" (the relevant literature is discussed below) there has not been a comparative cross-linguistic study of queer ways of speaking. A comparison of nine different argots suggests that the prevalence of speech play is a unifying feature across all argots. The paper outlines the various forms of speech play commonly found in queer argots, suggesting that shared linguistic humor is a common feature in the development of these varieties. The importance of these distinct varieties within queer culture is demonstrated with examples of these argots being used in mock translations of highly recognizable texts. The results suggest that queer forms of speech play and verbal art present an important and understudied aspect of LG$\mathrm{BTQ}+$ cultures.

The varieties considered here (listed in Table 1) are not all necessarily intended as "secret" ways of speaking, but they are often described as such by speakers. They are all embedded within a more broadly-used language, which I shall call the 
'matrix language' (following Myers-Scotton 1993). Queer argots typically involve different degrees of lexical replacement in which queer neologisms replace words in the matrix language. Although these varieties almost always draw most of their grammar and lexicon from the matrix language, they often include fairly large amounts of borrowing from other languages. Often, this involves a sort of 'core' vocabulary drawn from some other minority group. Lubunca and Kaliardà (queer varieties of Turkish and Greek, respectively) both draw heavily on Romani, while Polari borrows heavily from Italian (by way of Lingua Franca), and Pajubá (spoken by travestis in Brazil) builds on a core vocabulary borrowed from Yoruba.

\begin{tabular}{|c|c|c|}
\hline Name of variety & $\begin{array}{l}\text { Matrix language } \\
\text { (location) }\end{array}$ & References \\
\hline bahasa gay & $\begin{array}{l}\text { Indonesian (Indone- } \\
\text { sia) }\end{array}$ & Boellstorff 2004a, 2004b, 2005 \\
\hline Gayle & English (South Africa) & Cage 2003 \\
\hline isiNgqumo & Zulu (South Africa) & $\begin{array}{l}\text { Msibi 2013; Ntuli 2009; Rudwick } \\
\text { 2010, 2011; Rudwick and Msibi } \\
\text { 2016; Rudwick and Ntuli } 2008\end{array}$ \\
\hline Kaliardà & Greek (Greece) & Montoliu 2005 \\
\hline khabal'stvo & $\begin{array}{l}\text { Russian (Russia, } \\
\text { Ukraine) }\end{array}$ & Nemtsev 2007; Ukolova 2009 \\
\hline Lubunca & Turkish (Turkey) & $\begin{array}{l}\text { Biondo 2017; Kontovas 2012; } \\
\text { Kyuchukov and Bakker } 1999\end{array}$ \\
\hline oxtchit & Hebrew (Israel) & Levon 2010a, 2010b \\
\hline Pajubá (Bajubá) & Portuguese (Brazil) & da Cruz and de Paola Tito 2016 \\
\hline Polari & $\begin{array}{l}\text { English } \\
\text { (Great Britain) }\end{array}$ & Baker 2002a, 2002b \\
\hline Swardspeak & $\begin{array}{l}\text { Tagalog, Cebuano } \\
\text { (Philippines) }\end{array}$ & $\begin{array}{l}\text { Casabal 2008; Manalansan 2003; } \\
\text { Pascual } 2016\end{array}$ \\
\hline
\end{tabular}

Table 1. Queer argots considered in this paper

Although I include additional examples from gay male slang in American English and Mexican Spanish, the primary focus here is on queer varieties that have local names (so that they are clearly recognized as distinct language varieties). In this analysis, some varieties receive more attention than others both because of wideranging variation in structure and use and because of the lack of detailed documentation and description for some varieties. Although having a name might suggest that these varieties are highly enregistered (Agha 2003), they differ widely in terms of difference from the matrix language. Polari is clearly the most divergent variety and includes differences in syntax and morphology in addition to lexical replace- 
ment (see Baker 2002a, 2002b). Indeed, the Summer Institute of Linguistics' Ethnologue treats Polari as a distinct language, separate from English (Simons 2017). In contrast, Levon (2010: 133) finds only 28 oxtchit words that differ from everyday Hebrew and Nemtsev (2007: 24-25) argues that khabal'stvo involves only gendered ways of using stereotypically feminine forms of standard Russian and contains no unique vocabulary of its own. Thus, these varieties range from those which might be seen as nothing more than exploiting the gendered indexical meanings found in any language to those that might even be considered distinct languages.

Given the diversity across these varieties, it may be that their common exploitation of speech play (particularly in the service of gender play) may be their only unifying characteristic. After discussing my choices of queer and argot to label these varieties, I will survey features of speech play and gender play within these varieties and, finally, discuss how these forms of speech and gender play emerge in queer forms of verbal art.

\subsection{Why "queer"?}

Although most of these varieties are used by gay men, others are also used by trans women. Others are associated with gender identity categories that don't easily align with hegemonic Western assumptions about gender and sexuality (cf. Davis 2014). While the varieties considered here are all primarily associated with individuals who were assigned male gender at birth, there are certainly similar forms of speech play used by women and trans men (e.g. Livia 2000; Queen 1997; Blackwood 2014; Zimman 2014). Because there is no direct correspondence across the different sexual and gender categories associated with these argots, I have chosen to use queer as a general term for cultural practices/categories in opposition to gender and/or sexual normativity (see Barrett 2001).

The variation across these queer communities can be illustrated by comparing three groups: skesanas (speakers of isiNgqumo), travestis (speakers of Pajubá), and bakla' (speakers of Swardspeak). These three categories do not align with the more hegemonic categories of "gay men" and "trans women." Each of these three groups refers to individuals who were assigned male gender at birth and adopt feminine forms of gender expression. However, the three groups also differ in important ways. Skesana identity emerged in mining camps in the KwaZulu-Natal region of South Africa (Rudwick 2011; Rudwick and Msibi 2016) and follows a penetrative system of sexual categorizations in which the active partner in gay sex is considered heterosexual (see Barrett 2003; Cameron and Kulick 2003). In terms of sexual practice, skesanas (claim to) always take the passive role in sex with men and their partners are generally seen as heterosexual men in the outside community (Ntuli 2009: 181). Sex between two skesanas is stigmatized as unnatural and abnormal. Brazilian travestis are similar to skesanas in that they adopt feminine appearance and mannerisms. Also like skesanas, the partners of travestis are generally seen as heterosexual and sex between two travestis is stigmatized. However, unlike ske- 
sanas, travestis are quite open about being both the active and passive partner and men regularly pay travestis to penetrate them (Kulick 1998: 107). Finally, bakla' identity is similar to travestis and skesanas in terms of having feminine gender expression, but bakla' sexual practice is independent from gender identity so that bakla' may have partners who identify as straight, as gay, or as bakla' themselves. Like travestis, bakla' may be active or passive partners (Manalansan 2003). The key distinctions between these three groups are outlined in Table 2 below:

\begin{tabular}{|l|l|l|l|}
\hline Group & Partner identity & $\begin{array}{l}\text { Sex with others in group } \\
\text { stigmatized? }\end{array}$ & Role in sex \\
\hline skesana & heterosexual & yes & $\begin{array}{l}\text { always passive } \\
\text { partner }\end{array}$ \\
\hline travesti & heterosexual & yes & $\begin{array}{l}\text { active or passive } \\
\text { partner }\end{array}$ \\
\hline bakla' & varies & no & $\begin{array}{l}\text { active or passive } \\
\text { partner }\end{array}$ \\
\hline
\end{tabular}

Table 2. Key differences between skesana, travesti, and bakla' identities

Because of such differences across categories, it would be wrong to equate any of these identities with that of gay men (or trans women). The identities associated with the various argots considered here are culturally specific and do not necessarily align with one another.

In addition to these categories being distinct from one another, there is no one-to-one relationship between knowledge of a queer argot and actual membership in an imagined queer community (see Barrett 1997). Thus, Boelstorff (2004a, 2004b) notes that there are people who do not identify as gay but understand and use bahasa gay. Similarly, Casabal (2008: 70) suggests that knowledge of Swardspeak has spread beyond queer communities in the Philippines. Msibi notes that in addition to skesanas, isiNgqumo is known and used by women and men who identify as gay (2013: 266). Similarly, varieties like oxtchit and khabal'stvo may be used primarily by mainstream gay men to mock effeminate men (Levin 2010a, 2010b; Ukolova 2009). Thus, the indeterminacy of queer is determined to capture both a range of sexual categorizations across cultures as well as the "fuzzy" boundaries between sexual categories within any given culture.

\subsection{Why "argot"?}

For at least fifty years, linguists and anthropologists have debated the exact social functions of queer slang varieties. In the 1960s, the debate largely centered around whether or not gay and lesbian varieties emerged in response to the oppression and marginalization of queers or as a result of the emergence of shared culture and a sense of community. For example, Sonenschein (1969) argued that gay/ 
lesbian slang was not intended to provide protection through secrecy, but rather was the result of shared cultural norms within lesbian and gay communities. Sonenschein compared what he called "sex terms" (those referring to sexual practices) and "role terms" (those referring to particular types of individuals within gay and lesbian culture). He found that there were significantly more role terms compared to sex terms and that sex terms were more likely to overlap with slang forms used by heterosexual contemporaries. Thus, Sonenschein argued that the "homosexual's language" was not simply a way to keep sexual activity a secret. In addition to secrecy involving sexual acts, early research focused on the concealment and control of sexual identities, such as asking a man if he is "a friend of Dorothy" to determine whether or not he is gay (e.g. Hayes 1981; Painter 1981).

The degree to which queer varieties could be considered "secret" depends on a number of factors, including degree of difference from the matrix language. A variety with higher amounts of lexical replacement (like Polari) is more suited for secrecy than a variety with little or no unique vocabulary (like khabal'stvo or oxtchit). Boelstorff $(2004 a, 2005)$ notes that bahasa gay is not semantically opaque so that outsiders could easily recognize what is being said. In arguing against "secrecy" as the primary function of bahasa gay, Boelstorff uses the term "language of belonging" to emphasize the fact that bahasa gay serves as a way to build community more than as a means of ensuring secrecy. However, as Levon (2010a, 2010b) demonstrates, oxtchit is used not so much to promote belonging to community, but more to mock effeminate men as a way of policing community boundaries. In this sense, oxtchit and khabal'stvo could be considered "languages of exclusion" more than they are "languages of belonging."

The binary opposition between "maintaining secrecy" and "forming community" clearly misses the complex and varied social functions of secrecy (see Debenport 2015, in press). This opposition reduces the range of social functions queer varieties might play to only two, both primarily defined in opposition to heteronormative culture. In addition, such a binary opposition fails to recognize that communities are themselves constituted through secrecy and shared knowledge (Debenport 2015), so that argots serve both functions simultaneously. As Chauncey notes in his discussion of argot in early 20th-century New York:

Men's use of gay argot fostered their sense of collective identity. The very fact that men could understand a common code emphasized their membership in a group to whose codes they alone were 'wise,' and became a sign by which they distinguished themselves from outsiders. Indeed, it made them the insiders in a world that normally cast them as outsider, and many men treasured the sense it gave them of participating in a secret society. (Chauncey 1994: 287)

Because secrecy is not relevant in the case of oxtchit, Levin (2010a) suggests using Halliday's term, anti-language rather than calling the variety an argot. Agha 
(2015) sees argots as a special class of slang. Because slang varieties and argots are never a language of its own (but rather, always a subset of matrix language), Agha argues that the term anti-language suggests that argots are more full-fledged "languages" than they actually are. Agha also notes that Halliday's idea of a language associated with an 'anti-society' or 'anti-reality' wrongly suggests that switching between registers involves movement from one society (or reality) to another (2017:312).

Here, I have chosen to retain the traditional argot label for several reasons. Like argots, these varieties all involve a subset of lexical substitutions and manipulations of the matrix language (rather than being distinct and independent languages). Also, although secrecy is certainly not the only (or even primary) function of these varieties, speakers often describe them as functioning as a sort of "secret code" that can be used to delineate community boundaries. The term also highlights the centrality of concealment and disclosure (i.e. the closet) within queer history. My choice of the term argot should not be seen as promoting any single social function of these varieties. While these queer argots certainly have indexical potential for conveying queer identities, they may also do much more. They may mark femininity as a personal trait, they may mock stereotypes of male femininity, they may mark an ally's affiliation with queer communities, they may be used to exclude outsiders from queer communities, and they may serve to exclude other queers.

\subsection{Queer argot as verbal art}

Although studies of queer argots have highlighted quite distinct social functions of these varieties, one seeming constant is that queer argots are consistently associated with displays of humor. As Montoliu notes for Kaliardà (the Greek argot):

Speech play and conscious linguistic engineering are at the very base of Kaliardà: new words are created all the time, replacing old ones or modifying their original meaning. Many of these new words are metaphorical synonyms that involve a funny definition of the word or are based on a comic analogy. (Montoliu 2005:308-309)

While queer argots seem to be consistently used to display verbal agility and wit, the humor associated with queer argots is typically linked with additional social functions. Thus, by emphasizing the role of speech play in the formation of queer argots, I do not mean to dismiss any of the other functions these varieties may serve. The various and competing functions described for queer argots are strikingly similar to the various uses of play languages (like Verlan, or Pig Latin) described by Joel Sherzer:

Play languages are used to mark ethnic and social identity, to keep secrets, and to express opposition to the hegemonic rule of uppermiddle-class and education-oriented standard languages and 
dialects. They highlight speakers on display, showing off verbal virtuosity in an interactional, performance, and competitive mode. And, like all (...) forms of speech play (...), they can be used as pure play, simply for the fun of it. (Sherzer 2002: 29)

Speech play may be an important component in the formation of new varieties (see Gilmore 2015) and in the elaboration of existing languages (see Peterson and Webster 2013). Thus, the presence of speech play in queer argots is not in any way unique to queer. However, in comparing argots across cultural contexts, a number of similarities emerge. In particular, forms of speech play are typically coupled with forms of gender play. By gender play, I mean uses of language that challenge the hegemonic boundary between masculinity and femininity. Challenges to gender normativity are found throughout the lexicons of queer argots and across studies of queer discourse. This need not mean that challenging gender norms is a basic part of queer identity. Indeed, queer argots like khabal'stvo or oxtchit are described as being used by gender normative men to mock effeminate gay men (although even here they index gender non-normativity). Thus, it is common for speech play to coincide with gender play. For example, puns are a common type of neologism in queer slang, such as heteroflexible (American gay slang for "a man who identifies as straight but has sex with men"). Examples from Mexican Spanish gay slang include machomenos (a pun on mas o menos "more or less" to describe a man whose masculinity is questioned) and musculoca ("muscle queen," a pun on musculoso "muscular" and loca "queen") (Bernal 2007). These puns not only play with the ambiguity of phonological similarity, but also play with the ambiguity of outward displays of heterosexual masculinity (that might be secretly queer).

Verbal skill is often highly valued in queer cultures (e.g. Barrett 2017; Hall 1997; Harvey 2000, 2002; Murray 1978). The importance of language play in queer culture can be seen in the long tradition of producing dictionaries of gay and lesbian slang (e.g. Baker 2002a; Fessller and Rauch 1997; Legman 1941; Max 1988; Paterkin 2003; Reuter 2006; Rodgers 1972; Summerbell 1985). While many uses of queer argot involve redirection of stereotypes concerning gendered, they also demonstrate that play with gender is largely achieved through play with language. By focusing on speech play, I hope to highlight the way in which these argots reflect queers taking great pleasure in humorous interactions with other queers. After first discussing linguistic forms of gender play in queer cultures, I will discuss play involving multilingualism, the use of play languages (like Pig Latin), speech play involving morphological productivity, and lexical substitutions based on play with phonology and semantics. The paper concludes by discussing the genre of mock translations as a form of queer verbal art which build upon the forms of speech play associated with queer argots. 


\section{Speech play and gender play}

Forms of gender inversion are common across queer cultures (see, for example, Johnsen 2008 on gender inversion in gay male speech in Norwegian, French and English). This is not to imply that all queers are gender non-normative. Indeed, gendered language may be used to mock and marginalize effeminate gay men (as with khabal'stvo and oxtchit discussed above). However, forms of indexical disjuncture (Barrett 2017) that highlight the rift between sex and gender repeatedly surface in queer discourse. In terms of queer argots, varieties like khabal'stvo and oxtchit seem to involve little more than gender non-normative language use (Levin 2010a, 2010b, Ukolova 2009). Linguistic challenges to gender normativity occur throughout these argots. Indeed, most of the forms of speech play discussed below also involve gender play to some degree.

Speech play involving gender is also common in queer contexts where argots have not emerged. For example, in languages with grammatical gender, queer speakers often manipulate morphological markers of gender for various stylistic and interactional effects. For example, queer speakers of Hausa (Gaudio 2014), Hebrew (Bersthling 2014; Levin 2010b), Hindi (Hall 2002), and Portuguese (Borba and Ostermann 2007, 2008) all manipulate morphological markers of gender in various ways. As with argots (like oxtchit), manipulations of grammatical gender may be used to marginalize out-group individuals (see Hall 2002). These manipulations of gender morphology are simply one component in broader forms of speech play. For example, Gaudio (2014) describes the ways in which 'yan daudu speakers of Hausa in Nigeria simultaneously manipulate gender morphology and forms of syntactic voice in speech play evoking stereotypes of gendered forms of agency. In addition to being combined with forms of grammar beyond gender, gender play with language also combines gender non-normative language with forms of normative gendered language to create innovative ways of speaking that are not easily categorized according to normative gender ideologies. These types of indexical disjuncture distinguish queer ways of speaking from heteronormative gender registers. Thus, for example, isiNgqumo incorporates large amounts of isihlonipho, a respect register used by (particularly rural) women (Rudwick and Msibi 2016). While isiNgqumo borrows heavily from isihlonipho in order to index femininity, the maintenance of distinction between isiNgqumo and isihlonipho is critical to maintaining the distinction between skesanas and women.

Given the central role of language in producing challenges to gender normativity, speech play and gender play are often indistinguishable in queer discourse. The examples of speech play that follow are often also be examples of gender play. These include non-normative use of gendered morphology (such as the use of French -ette) in Polari, the appropriation of registers that index femininity (as in khabal'stvo), and the use of feminine names (both to refer to other men and as forms of lexical substitution). Of course, there are also forms of speech play in 
queer argots that are independent of gender, including forms associated with masculinist cultures (such as borrowings from Cockney rhyming slang or sailors' slang in Polari). The following sections outline specific patterns of speech play that recur across various queer argots.

\subsection{Cross-language play}

Speech play often includes borrowing forms from other languages. Speakers often play with other languages spoken around them, such as with forms of Mock Spanish used in the United States (see Hill 1993, 1998) or the shm- reduplication borrowed from Yiddish into American English (e.g. happy shmappy). Forms of speech play are thus often sites where the effects of language contact can be observed (Heath 1984: 380). Among queer argots with a fair amount of lexical replacement, the range of languages donating words to queer varieties is quite broad. For example, the Kaliardà (Greek) lexicon contains borrowings from Italian, Romani, Turkish, English, French, Spanish, and Albanian (Montoliu 2005: 305). Lubunca (Turkish) contains borrowings from Romani, Arabic, Armenian, Bulgarian, English, French, Greek, Italian, Kurmanji, Ladino, and Russian (Biondo 2017; Kontovas 2012). Tagalog-based Swardspeak borrows from English, Spanish, Japanese, Bikol, and Hilagaynon (Pascual 2016:35), and Zulu-based isiNgqumo (which emerged in a comparatively isolated social context) contains borrowings from Xhosa and English (Msibi 2013). Although Levin finds that oxtchit contains only 28 words, those words include forms borrowed from Arabic, English, French, Spanish, Italian, and German (2010b: 134). Although speakers may be unaware of the historical origins of borrowed forms, the wide range of borrowings across multiple varieties suggests that speech play across language boundaries is a central component in the development of queer argots.

For some queer argots, the effects of language contact reflect the history of ethnic groups sharing the social marginalization experienced by queers. For example, Polari, Kaliardà, and Lubunca all contain borrowings from Romani while Pajubá is founded on a core vocabulary from Yoruba (da Cruz and Tito 2016). Polari also contains borrowings from Yiddish while Lubunca includes borrowings from Ladino. In these cases, language contact suggests overlap between different marginalized experiences in which queers interact with ethnic minorities who are also shut out of the dominant culture. The importance of sailors in queer history (and sexual practices) can be seen in the many borrowings from Lingua Franca in Polari and related Italian borrowings in Kaliardà and Lubunca. Given the current global dominance of English, it is not surprising to find English borrowings not only in queer argots but in local forms of gay slang such as Polish (Dyszak 2016) or Spanish (Bernal 2007).

The place of foreign languages in queer culture is wide-ranging, from the stereotype of the highly fluent gay male French teacher to the camp humor of translating "dirty" phrases in humorous foreign language phrasebooks marketed to gay men (Barrett 2003). The use of foreign languages is a common aspect of camp 
humor. For example, Harvey (2000: 243) lists the use of French as a basic form of camp linguistic style. Speakers of Polari often code-switched between Polari and French both to further obscure their speech and to exploit the camp associations of French as an index of aristocracy (Baker 2002: 57). While the use of French by British queers may have sometimes been serious, it seems to have more commonly be exploited as a mock variety. The use of that's your actual French by Julian and Sandy (Baker 2002b: 56) emphasizes the satirical nature of their frequent switches into French. Such camp play with language has a long tradition. For example, one of the earliest gay travel guides, Nerf, Asti and Dilldock's 1949 The gay girl's guide, includes camp references to Russian:

Since war with Russia remains a potentiality for many years, the following are included for use if you become a P.O.W. and have an appropriate lieutenant or sergeant of the camp guards to practice on... I'd like to suck your cock Yah ho-TYEL-boooy poso-SART varsh KOO-ey

I sure like your cock and balls but you need a bath

Mnnyeh O-chen NRAV-yar-tsar varshee MOO-doo no vahm NOOGE-no BARN-yar.

(Nerf et al 1949: 18, reprinted in Hagius 2010)

Within queer argots, we see similar play across languages in the formation of words with elements taken from more than onelanguage. For example, the isiNgqumo verb for "to break up/leave" uyaangitek'sela incorporates the English word taxi (teksi-) (Ntuli 2009: 76). The Polari word for television (vardavision) is similar, combining the Italian root varda- (to see) with the morpheme -vision (Baker 2002a). Similarly, Peña (2004: 244) discusses the term pájaration, "gayness" combining the Cuban slang term for gay men, pájaro, with the English nominalizing suffix -ation. Humorous combinations of language may be purely indexical rather than actually involving borrowing. For example, a recent article on drag balls in Portland, Oregon refers to a drag category of art heaux, playing off of French spelling conventions to create mock sophistication in the mock French spelling of English "hos" (whores) (Prado 2017).

Of the queer argots considered here, Kaliardà makes the most widespread use of neologisms formed by combining morphemes from different languages. Montoliu (2005) notes that Kaliardà regularly replaces some Greek prefixes with forms from other languages. For example, the Greek prefix palio- "old" may be replaced by either phuro- (from Romani) or veko- (from Italian vecchio). Similarly, the Greek intensifier theo- (etymologically from Theós "God") is replaced with the prefix godo(from English God). Another common pattern in Kaliardà is to build compounds with roots from two different languages. For example, the Kaliardà name for Paris, Mutzótopos ("vagina place"), combines the Romani word for vagina (mutzó) with the Greek form tópos “place.” Additional Kaliardà examples of cross-language morphology are given in Table 3 : 


\begin{tabular}{|c|c|c|c|}
\hline Kaliardà form & First element & Second element & Gloss \\
\hline balo-múskulos & balo "fat" < Romani "pig" & $\begin{array}{l}\text { múskulos Italian } \\
\text { "muscled" }\end{array}$ & muscled \\
\hline laisotémba & lachó Romani “good” & tempo Italian “weather" & summer \\
\hline but-gratsiozo & but Romani “very” & $\begin{array}{l}\text { grazioso Italian "graceful" } \\
\text { (pun on grazie - "thank } \\
\text { you") }\end{array}$ & thank you \\
\hline tzinavótopos & $\begin{array}{l}\text { tzinavo Kaliardà "to be } \\
\text { gay" }\end{array}$ & tópos Greek “place” & London \\
\hline mutzótopos & mutzó Romani “vagina” & tópos Greek “place” & Paris \\
\hline
\end{tabular}

Table 3. Cross-language morphology in Kaliardà (after Montoliu 2005)

These forms of cross-language morphology reflect a more general pattern of queer speech play involving the formation of humorous morphological blends (e.g. Polari fantabulosa fantastic + fabulous + a). They also highlight the role of foreign languages and code-switching as sources for speech play within queer cultures. This queer play with foreign languages can also be seen in camp uses of French by English speakers, the proliferation of phrase-books as a source of gay male humor (Barrett 2003), and the widespread borrowings found across queer argots. In addition to speech play involving language contact, queer argots often involve the use of play languages similar to Pig Latin (Sherzer 2002: 26-29).

\subsection{Play languages}

Play languages manipulate linguistic forms through a basic set of simple rules to alter the phonological form of words. These rules may rearrange sounds in a word (as in Pig Latin) or iteratively infix syllables into words, as in Ubbi Dubbi (Yu 2008). Polari, Swardspeak, and bahasa gay all include forms that clearly originated in play languages. For example, Swardspeak contains a set of words that follow the same basic pattern found the French play language Verlan in which words are pronounced backwards (or backslang). Swardspeak contains examples of both Verlanstyle syllable reversal (a, b, and c in Table 4) and backslang (d in Table 4). Both forms may also occur with an additional final [s] (as in c and d in Table 4).

\begin{tabular}{|l|l|l|}
\hline Tagalog & Swardspeak & Gloss \\
\hline a. sibat & batsi & toleave \\
\hline b. matanda & damatan & old \\
\hline c. itits & titi & cock (penis) \\
\hline d. alaws & wala & nothing \\
\hline
\end{tabular}

Table 4. Swardspeak syllable reversal (Pascual 2016: 35) 
Backslang is also a basic way of forming words in Polari (Baker 2002: 31), although Polari backslang is based on spelling (rather than pronunciation). Examples include ecaf [ijkæf] (later shortened to eke ([ijk]) for "face", riah [rije] for "hair", and esong [esay] for "nose." The use of backslang is not unique to Polari, so that some of these forms overlap with other British slang varieties.

Another example of a queer play language can be seen in bahasa gay (Boellstorff 2005: 190) in which the first syllable (and the onset of following syllable) are maintained with remainder of word being replaced with a suffix, either -es or -ong. Examples of -ong/-es replacement are given in Table 5 below:

\begin{tabular}{|l|l|l|}
\hline $\begin{array}{l}\text { Indonesian } \\
\text { base form }\end{array}$ & Gloss & $\begin{array}{l}\text { New bahasagay } \\
\text { term }\end{array}$ \\
\hline banci & waria & béncong/bences \\
\hline berapa & how much? & brépong \\
\hline dandan & put on makeup & déndong/dendes \\
\hline lelaki & man & lékong / lekes \\
\hline sakit & sick ('attracted to the same sex' in bahasa gay)) & $\begin{array}{l}\text { sékong/ sékes / } \\
\text { sekes }\end{array}$ \\
\hline
\end{tabular}

Table 5. -ong and -es suffixation in bahasa gay (Boellstorff 2005)

Following the pattern of Javanese speech levels, it is typical for there to be only one bahasa gay form in any given utterance (Boelstorff 2004a, 2005). However, it is possible to use the suffixal substitution pattern iteratively as in the example in Table 6 below:

\begin{tabular}{|l|l|l|}
\hline Standard Indonesian & $\begin{array}{l}\text { Lelaki cakep, [kamu] mau } \\
\text { ngésong [fellate] }\end{array}$ & boy cute [you] want fellate \\
\hline bahasa gay & Lékes cékes, méses ngéses? & \\
\hline
\end{tabular}

Table 6. Substitution in bahasa gay (Boelstorff 2005)

Play languages serve a wide range of functions that are similar to the range of functions associated with argots more generally. These play languages are primarily manipulation of the phonological form of words. Of course, speech play may also involve the manipulation of morphology. The following section considers the elaboration and development of playful morphological paradigms in queer argots.

\subsection{Morphological play and paradigm elaboration}

Agha (2015: 324) notes that the emergence of slang forms often involves analogous uses of morphology in which affixes are used in contexts that do not occur within a standard variety (such as fund-age in American English slang). We see this 
exact pattern in the extension of -ette as a productive suffix in Polari. In terms of indexical potential for camp meanings, the suffix - ette hits the trifecta; it may be used as a diminutive (kitchenette, cigarette), it indexes femininity (majorette, Paulette), and it is borrowed from French (serviette, coquette). Given these associations, one would almost expect that expanded use of -ette would become a basic feature of Polari. Examples from Polari include masterpiecette, glassette, telegramettte, restaurantette, futurette, and tourette (Baker 2002b: 60).

Other than the cross-language compounds in Kaliardà mentioned earlier, patterns of compounding in queer argots are not particularly distinct from those found in other languages. However, compounds in Polari and in American gay slang are typically humorous and playful, suggesting their likely origin as forms of speech play. The examples in Table 7 below show compounds building on the Polari root ogle meaning "eye":

ogle = eye

ogle fakes - glasses (fake = "false")

ogle riah - eyelashes (riah = backslang for "hair")

ogle fake riah - false eyelashes

ogle filters - sunglasses

ogle riders - eyebrows

Table 7. Compounds building on ogle "eye" in Polari (Baker 2002b: 60)

Here, the addition of multiple Polari terms (as in ogle fake riah) produces humor by over-extending existing Polari patterns. Perhaps the most productive queer compounding pattern is the use of $X$ queen found in the majority of gay male English varieties (including Polari, Gayle, and U.S. gay slang). These queen compounds were used to refer to various "types" of gay men based either on their personal traits or their sexual desires. Examples of queen compounds from American English gay slang are given in Table 8 below:

\begin{tabular}{|l|l|l|l|}
\hline X queen & Meaning & X queen & Meaning \\
\hline closet queen & gay man who isn't out & $\begin{array}{l}\text { seafood } \\
\text { queen }\end{array}$ & cruises for sailors \\
\hline éclair queen & rich homosexual & size queen & wants large penis \\
\hline $\begin{array}{l}\text { highway } \\
\text { queen }\end{array}$ & gay truck driver & store queen & addicted to shopping \\
\hline $\begin{array}{l}\text { leather } \\
\text { queen }\end{array}$ & leatherman & toilet queen & $\begin{array}{l}\text { cruises public rest- } \\
\text { rooms }\end{array}$ \\
\hline quilroad & cruises for hobos & Xerox queen & $\begin{array}{l}\text { all his partners look } \\
\text { alike }\end{array}$ \\
\hline
\end{tabular}

Table 8. Compounds based on "queen" (from Rodgers 1972) 
Compounding patterns may also build on rhyming patterns as in British and American gay slang terms building on rhymes with the word fag and based on the compound fag hag "a straight female extremely fond of the company of gay men" (Reuter 2006: 69):

\begin{tabular}{|l|l|}
\hline fag bag & "A straight woman married to a gay man" (Reuter 2006: 68) \\
\hline fag drag & $\begin{array}{l}\text { "A drag king who sometimes performs a gay male identity" (Baker } \\
\text { 2002a: 118) }\end{array}$ \\
\hline fag mag & "A magazine...geared towards gay men or lesbians" (Baker 2002a: 118) \\
\hline $\begin{array}{l}\text { fag mag- "An event..that draws the rapt attention of gay men" (Reuter 2006: 68) } \\
\text { net }\end{array}$ & $\begin{array}{l}\text { "heterosexual man who..socialize[s] with...gay men" (Baker 2002a: } \\
\text { fag stag }\end{array}$ \\
\hline draghag & "someone who likes the company of drag queens" (Baker 2002a: 112) \\
\hline hag fag & $\begin{array}{l}\text { "A gay man who likes to hang out with lots of women" (Baker 2002a: } \\
\text { 140) }\end{array}$ \\
\hline taghag & $\begin{array}{l}\text { "someone who likes to wear expensive designer clothing" (Baker } \\
\text { 2002a: 200) }\end{array}$ \\
\hline spag fag & "a gay man who is sexually attracted to Italian men" (Baker 2002a: 196) \\
\hline spag hag & "anyone who finds Italian men sexy" (Baker 2002a: 196) \\
\hline staghag & "a person who enjoys the company of straight men" (Baker 2002a: 197) \\
\hline
\end{tabular}

Table 9. Compounds based on the fag hag pattern

These examples suggest that speech play involving morphological patterns is central to the expansion of queer argot lexicons. In addition to the introduction of neologisms, argots develop through the replacement of matrix language words with new forms unique to the argot. In contrast to the cross-language replacements discussed above, these lexical substitutions often involve replacing one word in the matrix language with another phonologically similar form (also from the matrix language). The following section discusses these processes of lexical substitution where, again, speech play serves a central role.

\subsection{Lexical substitution}

One of the most common ways in which queer argots expand is through the replacement of vocabulary with other words (or names), usually based on phonological similarity. In Gayle and Swardspeak, these substitutions involve feminine proper names. The amount of phonological overlap varies across varieties. In Gayle, replacement words may only share an initial consonant with the word they substitute while substitutions in Swardspeak and bahasa gay overlap by at least one syllable. As is typical for argots, a single lexical substitution is inserted into otherwise 
unaltered utterances in the matrix language. For example, in Table 10 below, the Indonesian form lapar (hungry) is replaced with lapaangan (open field):

\begin{tabular}{|l|l|l|}
\hline Standard Indonesian & Saya sudah lapar dua jam. & $\begin{array}{l}\text { literal translation } \\
\text { hours. }\end{array}$ \\
\hline bahasa gay & $\begin{array}{l}\text { Saya Sudah lapaangan dua } \\
\text { jam. }\end{array}$ & $\begin{array}{l}\text { I already open field two } \\
\text { hours }\end{array}$ \\
\hline
\end{tabular}

Table 10. Lexical substitution in bahasa gay (Boellstorff2005: 191)

Boellstorff (2005: 191) compares this example to something like English "I've been Hungarian for two hours" where a single word is replaced with a word that sounds similar. Boelstorff describes the prototypical pattern as overlap with the initial CVC syllable, i.e. replacement by a form based on the first syllable of a word (plus the following onset if the first syllable doesn't have a coda). For example, the Indonesian form bodoh (pedicab) is replaced with bodrex (cough medicine). In actual practice, however, the size of overlap may be longer (lapar > lapangan; semak > semangka) or shorter (tidak > tinta). Additional examples are given in Table 11 below:

\begin{tabular}{|l|l|l|l|}
\hline bahasa gay term & Original meaning & Indonesian replaced & Meaning \\
\hline bodrex & cough medicine & bodoh & pedicab \\
\hline ciptadent & brand of toothpaste & cium & to kiss \\
\hline émbér & bucket & émang & indeed \\
\hline jelita & lovely & jelek & bad \\
\hline lapangan & open field & lapar & hungry \\
\hline semangka & watermelon & semak & tolike \\
\hline tinta & tint & tidak & no \\
\hline
\end{tabular}

Table 11. Lexical substitutions in bahasa gay (after Boellstorff 2004: 255)

Lexical replacement may involve chains of substitution that further obscure the original form in the matrix language. For example, Polari contains a number of forms borrowed from Cockney rhyming slang (Baker 2002b: 30) such as mince pies as a replacement for eyes. Some rhyming slang forms seem to be unique to Polari, such as the color of his eyes to mean "penis size." The common pattern is for a rhyming slang term to be reduced to the first (non-rhyming) part. For example, feet is first replaced by the rhyming form, plates of meat, which is then reduced to plates. As the reduced form nolonger shares phonological form with the original form, the relationship between the substitute form and the original is only recoverable if one is also familiar with the rhyming slang form. Examples are given in Table 12 below: 


\begin{tabular}{|l|l|l|}
\hline Polari word & Rhyming slang form & Gloss \\
\hline barnet & Barnet Fair & hair \\
\hline hampsteads & Hampsteads Heath & teeth \\
\hline minces & mince pies & eyes \\
\hline plates & plates of meat & feet \\
\hline scotches & Scotch peg & leg \\
\hline
\end{tabular}

Table 12. Cockney rhyming slang forms in Polari (Baker 2002b: 30)

As noted above, both Gayle and Swardspeak use lexical substitutions involving proper names. In both varieties, these replacements typically involve feminine proper names. Speech play involving feminine names is a basic feature of queer argots. For example, Cage notes that the practice of referring to other men with feminine names was a common practice in 18th century Molly Houses in Britain, where the substitute names were known as "maiden names." Cage quotes a 1709 letter to the Tattler of London complaining about "Petty Fellows" calling one another "Betty" and "Nelly" in public (Cage 2003: 29). The replacement of men's names with feminine forms is a common practice in Polari. Baker gives the examples of Martin > Martina and Harold > Harriett (2002b: 14). Similar replacements in U.S. gay male slang are reported by Rogers (1972), including Robert $>$ Roberta, Donald > Donna, and Johnny > Jenny.

Rogers also gives examples of feminine names used to refer to specific "types" of gay men in gay U.S. slang of the 1960s. Rogers' examples include forms based on phonology (e.g. Bathsheba for "one who frequents gay bath houses") and forms based on cultural references. For example, a gay man who "goes from one tragic episode to another" is called Camille, after the main character in American adaptations of the Alexandre Dumas (fils) novel La Dame aux Camélias. Similarly, a "gay hippie" was called Ophelia after the character in Hamlet (who put flowers in her hair like a hippie). Examples of this use of names are given in Table 13 below:

\begin{tabular}{|l|l|}
\hline Abigail & $\begin{array}{l}\text { "middle-aged homosexual whose approach to life... [is] conservati- } \\
\text { ve" (17) }\end{array}$ \\
\hline Bathsheba & "frequenter of the baths" (28) \\
\hline Camille & "homosexual who goes from one tragic episode to another" (40) \\
\hline Erma & "a well-meaning fuck up" (75) \\
\hline Katherine & "male homosexual when he appears in the role of hostess" (120) \\
\hline Minny & "a kind, but simple-minded sort" (134) \\
\hline Ophelia & "gay hippie" (144) \\
\hline
\end{tabular}

Table 13. Feminine names in US gay 1970s slang (Rodgers 1972) 
In Swardspeak (Casabal 2008), the names of (primarily) female celebrities are used to replace similar sounding words in either Tagalog or English. These substitutions can then be used in either language regardless of the original language of origin. In Swardspeak, substitutions are based on general phonological similarity so that there is no pre-specified phonological template (like that found in bahasa gay). As with bahasa gay substitutions, these Swardspeak forms are typically singleword substitutions in what is otherwise ordinary Tagalog or English. (e.g. There's a Cheese Whiz going around that you're Cathy Dennis). Examples based on Tagalog words are given in Table 14 below:

\begin{tabular}{|l|l|l|}
\hline Original Tagalog & Swardspeak replacement & Meaning \\
\hline chaka & Chaka Khan, Chuckie & ugly \\
\hline kati & Cathy Dennis, Cathy Santillan & horny (itchy) \\
\hline gutom & Tommy Lee Jones, Tommy Hilfiger & hungry \\
\hline lupit & Lupita Kashiwara & cruel \\
\hline irita & Rita Gomez, Rita Avila & to irritate \\
\hline mura & Mariah Carey & cheap \\
\hline mapagsamatala & Samantha Lopez & abusive \\
\hline huli & Julie Andrews, Julie Yap Daza & to catch/get caught \\
\hline mahal & Mahalia Jackson, Maharlika & expensive \\
\hline tsismis & Cheese Whiz & rumor(s), gossip \\
\hline
\end{tabular}

Table 14. Swardspeakname substitutions

Here, international and local Philippine celebrity and brand names are used to replace Tagalog words. Although the majority are women's names, there are also men (Tommy Lee Jones) and commercial brands (Cheese Whiz). Although Swardspeak does contain some forms with a semantic relationship (e.g. Camilla Parker Bowles to mean "evil stepmother"), for the majority of these substitutions, the relationship is purely phonological. Similar substitutions may be based on the phonological similarity of English words, as in Table 15 below:

\begin{tabular}{|l|l|}
\hline Name & Gloss/English root \\
\hline Winnie Monsod, Wynona Ryder & to win \\
\hline Lucita Soriano & to lose something/someone \\
\hline Sheryl Cruz & to share \\
\hline Crayola Khomeini & to cry \\
\hline
\end{tabular}

Table 15. English-based Swardspeaksubstitutions (Casabal 2008)

As in the Tagalog-based examples, there is no relationship between the original language and the nationality of the celebrity in the replacement. English to win can be replaced by either an American (Wynona Ryder) or a Philippine (Winnie 
Monsod) celebrity. Indeed, the name need not actually be associated with an actual person. For example, Crayola Khomeini is not an actual woman, but is simply a humorous invented name (which follows the broader speech play pattern in Swardspeak as well as play across languages).

A similar pattern of substitutions involving women's names is found in Gayle. According to Cage (2003), the pattern first emerged as part of moffietaal ("gay language"), an Afrikaans-based variety that originated among Cape "Colored" drag queens in South Africa. The pattern was borrowed by white speakers and became the basis for Gayle, an English-based argot. A few similar forms are found in isiNgqumo (Ruwick and Ntuli 2008: 449) including uBelinda ("blind" possibly borrowed from Gayle) and uTracy ("hermaphrodite"), a form restricted to townships and not found in Gayle (Cage 2003: 99). Thus, while particular forms may not have been borrowed from Gayle into isiNgqumo, the basic pattern seems to have spread across argots in different matrix languages within South Africa. As with substitutions in Swardspeak, women's names in Gayle may replace any part of speech. A subset of the substitutions in Gayle are based on semantics, as in Table 16 below:

\begin{tabular}{|l|l|}
\hline Golda & Jewish gay man (after Golda Meir) \\
\hline Sue-Ellen & alcoholic (after a character on the TV program Dallas) \\
\hline Isadora & to dance (after Isadora Duncan) \\
\hline Joan & a bitter gay man who treats others badly (after Joan Crawford) \\
\hline Sandra & one who always predicts bad events (from Cassandra in Greek mythology) \\
\hline
\end{tabular}

Table 16. Semantic-based Gayle substitutions (Cage 2003)

However, the majority of Gayle substitutions are based on phonological similarity. The range of phonological overlap between the substitute and original varies, ranging from full overlap (Nora < ignorant, Fatima < fat) to only sharing an initial consonant (Thelma $<$ thin, Nancy < nothing). Examples of substitutions in Gayle are given in Table 17 below:

\begin{tabular}{|l|l|l|l|}
\hline Name & Gloss & Name & Gloss \\
\hline Beatrice & eavesdropper (big ears) & Laura & lover \\
\hline Carol & to cry & Marjorie & margarine \\
\hline Dora & drink (n), drunk (adj) & Maureen & murder (n. or v.) \\
\hline Fatima & overweight (fat) & Nancy & nothing \\
\hline Geraldine & old (geriatric) & Nora & stupid (ignorant) \\
\hline Hilda & ugly (hideous) & Priscilla & policeman \\
\hline Hester & to hear & Rita & male prostitute (rent boy) \\
\hline Jessica & jealous & Thelma & thin \\
\hline Kaye & lubricant (KY brand name) & Tina & tiny \\
\hline
\end{tabular}

Table 17. Examples of sound-based lexical substitutions in Gayle (from Cage 2003) 
As with other argot substitutions, these forms are typically used as insertions (Muysken 2000) into utterances in the matrix language. Examples are given in Table18:

\begin{tabular}{l}
\hline If you run out of Kaye, try Marjorie. (Kaye = lubricant, Marjorie = margarine) \\
\hline Word's out that he Maureened his Laura. (Maureen = murder, Laura = lover) \\
\hline The Moira is Hilda tonight. (Moira = music, Hilda = hideous) \\
$\begin{array}{l}\text { Are you Marie?! Do you want Priscilla to pick you up? (Marie = crazy/mad, Prisci- } \\
\text { lla = police) }\end{array}$
\end{tabular}

Table 18. Example sentences from Cage's (2003) Gayle dictionary

Dictionary example sentences often express cultural ideologies that extend beyond language (Barrett 2003; Debenport 2015). These Gayle examples presuppose specific gay interactional contexts, even if largely imagined. They also illustrate the types of language play that surrounds queer argots not only in their emergence, but also in their transmission and their everyday use.

The various forms of lexical substitutions in bahasa gay, U.S. gay slang, Gayle, and Swardspeak all involve expanding argot vocabulary through forms of speech play. In most cases, this speech play overlaps with gender play, building on traditions of using feminine names in communication between gay men.

\section{The verbal artistry of queer argots}

The linguistic patterns found in speech play often form the basis for genres of verbal art. As Sherzer notes, this relationship blurs the division between speech play and verbal art:

The boundaries between speech play and verbal are are hard to delimit and are cultural as well as linguistic. At the same time, there are certain verbal forms where the relationship between the two is particularly salient and where it is quite clear that forms of speech play constitute the building blocks of verbal art. (Sherzer 2002: 70)

The forms of speech play associated with the emergence of queer argots also serve as "building blocks" for forms of queer verbal art. This relationship can be seen in the genre of mock translations in which well-known literary texts are "translated" into queer argots. This genre "rewrites" heteronormative cultural tropes as queer vernacular texts. Mock translations are certainly not restricted to queer culture. Non-queer examples include Andy Griffith's paraphrases of Shakespeare plays (Griffith 1964) and Mark Twain's humorous back-translation of his story “The Celebrated Jumping Frog of Calaveras County" in which Twain took the French version of his story and "clawed [it] back into a civilized language once more by patient, unremunerated toil" (Twain 1903). Because queer argots are not full 
languages (and only replace a subset of the matrix language grammar) and because they are built upon recognizable canonical texts, these "translations" are generally transparent to outsiders. They often build on texts that lend themselves to camp interpretations, such as the story of Cinderella and her evil stepsisters, rendered into Swardspeak in Table 19 below. Here, Cinderella is male and is named Chaka Khan (Swardspeak for "ugly" based on the Tagalog word chaka):

Chaka Khan knew Camilla Parker Bowles all too well: This was the same Churchill woman who constantly abused and berated his mother until the poor woman became a junk shop and went Lucrecia Kasilag, eventually perishing in a Lupita Kashiwara fashion.

Table 19. "A fairy tale" (Banal 2005)

The excerpt describes the abusive way that Chaka Khan's evil stepmother ("Camilla Parker Bowles") treated Chaka's actual mother who became a drug addict ("junk shop"), lost her mind ("went Lucrecia Kasilag") and died in a cruel ("Lupita Kashiwara") fashion. The camp trope of the evil stepmother is highlighted by the Swardspeak substitutions, such as the use of Camilla Parker Bowles (the rival of "gay icon" Princess Diana) to mean "evil stepmother."

Even in cases where the translated text is decidedly uncamp, elements of camp aesthetic may be inserted into the translation. For example, the opening the Polari translation of the Bible (see Table 20) uses the camp trope of juxtaposing elements of "high" culture with "low" experiences (Harvey 2000: 243). This creates an indexical disjuncture between the religious associations indexed through the linguistic structure and the gay cultural contexts mentioned in the text.

The Polari Bible
Seventh Edition
Containing the Authorized Version
Diligently translated out of the original
Appointed to be read in discotheques \& Turkish baths
tongue into High Polari by the Sisters ofPerpetual Indulgence \& Gentlem
Published in Manchester a notorious hotbed of the sin of Sodom by the Larlou Press.

Table 20. Polari Bible (Greening-Jackson 2015)

The text in Table 20 is inserted into an illustrated Biblical title page and uses a linguistic style associated with a sacred text (e.g. diligently translated out of the original tongue into High Polari). The camp juxtaposition comes from linking this religious language with public readings in gay contexts, such as discotheques, baths, and Manchester ("a hotbed of the sin of Sodom").

The Polari Bible also extends textual differences beyond the use of argot lexical substitutions in two main ways. First, the Polari lexicon is extended to replace reli- 
gious terminology in ways that serve to further queer the text. For example, spirit and angel are both replaced with fairy, maintaining the basic concept of a magicalsacred entity while substituting with a term (fairy) with clear queer indexical associations.

In the beginning Gloria created the heaven and the earth.

And the earth was nanti form, and void; and munge was upon the eke of the deep. And the Fairy of Gloria trolled upon the eke of the aquas.

And Gloria cackled, Let there be sparkle: and there was sparkle.

And Gloria vardad the sparkle, that it was bona: and Gloria medzered the sparkle from the munge.

And Gloria screeched the sparkle journo, and the munge she screeched nochy. And the bijou nochy and the morning were the first journo

Table 21. Opening of the Polari Bible (Greening-Jackson 2015)

Following the Polari tradition of replacing men's names with women's names, the Polari Bible replaces the majority of male names. Thus, David becomes Davina, Peter becomes Petra, Jesus becomes Josie, and Satan becomes Sadie. Here, God is also clearly feminine, renamed Gloria and always referred to with feminine pronouns. These additional changes to the text add to the camp style, using speech play to push beyond a direct "translation" to a distinctly queer form of verbal art.

Queer mock translations produce self-deprecating humor by rendering canonical heteronormative texts in queer argot. As Chauncey notes in his history of gay New York, gay argot "allowed men to see themselves as participants in the dominant culture by enabling them to see themselves in the interstices of that culture" (1994: 287). The translation of highly-recognized cultural tropes into queer discourse is one way of creating such interstices within heteronormative culture. The humor produced through viewing heteronormative culture through a queer lens is illustrated by the excerpt from a Julian and Sandy sketch in Table 22 below, from the $\mathrm{BBC}$ radio program Round the Horne. The sketch ("Bona Books") aired as part of an episode of the show called Journey to Uranus in 1968. In the sketch, Mr. Horne wanders into a bookstore run by Julian and Sandy where all of the books have been rewritten in Polari. In this excerpt, Sandy is telling Mr. Horne about the Polari edition of Shakespeare:

Sandy: We've got our own edition of Shakespeare, don't we?

Yeah, we've rewritten it ourselves in up-to-date Polari

It includes such things as Much Ado about Nanti, All's Bona that Ends Bona,

Two Omis of Verona, As They Like It

Horne: Isn't that As You Like It?

Sandy: Not really, but live and let live, I say.

Table 22. "Bona Books" (Simmonds 1968) 
Here, the humor is founded on viewing Shakespeare from a purely queer perspective. The outsider status indexed through the use of Polari is paralleled in the "translation" of As You Like It to As They Like It. Sandy's response of "live and let live" conveys a stance of acceptance for the way "they" (heterosexuals) like it, momentarily placing queer likes and desires at the center of normativity.

The humor of the queer perspective in this Julian and Sandy sketch exploits puns and double entendre beyond those specific to Polari. In the excerpt in Table 23, Sandy has asked Julian to recite the "Seven Ages of Omi" speech from the Polari version of As They Like It (omi = "man", palones = "woman"):

Julian: All the world's a stage

And all the omis and palones merely players;

They have their exits and their entrances

Sandy: That's true, Mr Horne, we all have our exits and our entrances.

Everyone one of us. I know I do. Oh, carry on Jules. Nice, nice.

Julian: Thank you. One omi in his time plays many parts...

Table 23. The Seven Ages of Omi

In this excerpt, camp humor again emerges from mixing "high" culture (Shakespeare) with a double entendre based on a "low" interpretation of the text. In the original, the line They have their exists and their entrances, refers to theatrical entrances and exits on and off a stage. However, Sandy's response (We all have our exits and our entrances... I know I do) raises the interpretation of entrances and exits of the body (i.e. where the body might be "entered" in sexual activity). Here again, the speech play afforded by Polari serves as the "building block" for camp verbal art that extends speech play beyond that available through the argot alone.

\section{Conclusion}

These mock translations show how queer argots come to be used in forms of verbal art founded in the camp cultural traditions of queer communities. While queer argots may be used for a variety of social purposes (secrecy, inclusion, exclusion, etc.), it is important to recognize that they also serve as a form of queer entertainment, a resource for the production of camp humor in queer interactions. The emergence of queer argots may teach us a variety of things about the historical experiences of queer communities, but one of the most important of these is that queers have a history of enjoying each other's company, laughing at themselves, and relishing in the breaking cracks in the hegemonic discourse of heteronormative society.

Scholars working in queer theory have given much attention to the role of abjection, shame, and insult in the formation of gay culture (e.g. Eribon 2005; Halperin 2007; Halperin and Traub 2010). Obviously, issues of marginalization or shame 
are important in the formation of queer argots. However, as Hall (2013) notes, focusing solely on the anti-social produces a static account of heteronormativity that prevents queer theory from adapting to changes in social norms. An account based on shame and insult also fails to recognize the pleasure that queers take in the formation of queer culture. Argots are (by definition) registers of shame - language varieties that enable marginalized groups to "hide" from normative society. But even in the formation of linguistic ways of hiding, queers were clearly laughing at the ways that language allows us to challenge normative assumptions about gender and sexuality. In the sense, queer argots can be seen in terms of "intimate grammars" (Webster 2010, 2015). Webster defines intimate grammar as an "emotionally saturated use of language that runs the risk of negative evaluation by outsiders (or non-outsiders) but are deeply and expressively feelingful for individuals" (Webster 2010: 187). A focus on queer shame or insult should not force us to lose sight of the equally important history of queer joy - that unique form of happiness produced by the discovery of a community where one may experience freedom from the solitary confinement of the closet.

\section{References}

Agha, Asif (2003). The social life of cultural value. Language \& Communication 23: 231-273. https://doi.org/10.1016/S0271-5309(03)00012-0

Agha, Asif (2015). Tropes of slang. Signs and Society 3(2): 306-330. https://doi.org/10.1086/683179

Baker, Paul (2002a). Polari: The lost language of gay men. London: Routledge

Baker, Paul (2002b). Fantabulosa: A dictionary of Polari and gay slang. London: Continuum

Banal, Yason (2005). A fairy tale. The Philippine Star. May 15. http://www.philstar.com/sunday-life/277659/fairy-tale

Barrett, Rusty (1997). The 'homo-genius' speech community. Livia, Anna, and Kira Hall, eds. Queerly phrased: Language, gender and sexuality. New York: Oxford University Press, 181-201

Barrett, Rusty (2001). Is queer theory important for sociolinguistic theory? Campbell-Kibler, Kathryn, Rob Podesva, Sarah Roberts, and Andrew Wong, eds. Language and sexuality: Contesting meaning in theory and practice. Stanford, CA: CSLI Publications, 25-43

Barrett, Rusty (2003). Models of gay male identity and the marketing of "gay language" in foreign-language phrasebooks for gay men. Sociolinguistic Studies 4(2): 533-562

Barrett, Rusty (2017). From drag queens to leathermen: Language, gender, and gay male subcultures. New York, NY: Oxford University Press

Bernal, J.G. (2007). El lenguaje homosexual. Mexico City: Paginas Prodigy. http://www.paginasprodigy.com/pqgantinatura/lg.pdf

Bershtling, Orit (2014). "Speech creates a kind of commitment”: Queering Hebrew. Zimman, Lal, Jenny L. Davis, and Joshua Raclaw, eds. Queer excursions: Retheorizing binaries in language, gender, and sexuality. New York, NY: Oxford University Press, 35-61 
Biondo, Raffaella (2017). Lubunca: lo slang queer del turco - Usi e funzioni sociolinguistiche a Istanbul e Berlino. Tesi di laurea. Università Ca'Foscari Venezia

Blackwood, Evelyn (2014). Language and non-normative gender and sexuality in Indonesia. Zimman, Lal, Jenny L. Davis, and Joshua Raclaw, eds. Queer excursions: Retheorizing binaries in language, gender, and sexuality. New York, NY: Oxford University Press, 81-100

Boellstorff, Tom (2004a). “Authentic, of course!": Gay language in Indonesia and culture of belonging. William L. Leap ad Tom Boellstorff, eds. Speaking in queer tongues: Globalization and gay language. Urbana and Chicago, IL: University of Illinois Press. 181-201

Boellstorff, Tom (2004b). "Gay” language and Indonesia: Registering belonging. Journal of Linguistic Anthropology 14(2): 248-268

Boellstorff, Tom (2005). The gay archipelago: Sexuality and nation in Indonesia. Princeton, NJ: Princeton University Press

Borba, Rodrigo, and Ana Cristina Ostermann (2007). Do bodies matter? Travestis' embodiment of (trans) gender identity through the manipulation of the Brazilian Portuguese grammatical gender system. Gender \& Language 1(1): 131-147.

https://doi.org/10.1558/genl.2007.1.1.131

Borba, Rodrigo, and Ana Cristina Ostermann (2008). Gênero ilimitado: a construção discursiva da identidade travesti através da manipulação do sistema de gênero grammatical. Estudos Feministas. 16(2): 409-432.

https://doi.org/10.1590/S0104-026X2008000200006

Cage, Ken (2003). Gayle - the language of kinks and queens: A history and dictionary of gay language in South Africa. Johannesburg, South Africa: Jacana

Cameron, Deborah, and Don Kulick (2003). Language and sexuality. Cambridge, UK: Cambridge University Press

Casabal, Norberto V. (2008). Gay language: Defying the structural limits of English language in the Philippines. Kritika Kultura 11: 74-101

Chauncey, George (1994). Gay New York: Gender, urban culture, and the makings of the gay male world, 1890-1940. New York: Basic Books

da Cruz, Luan, and Raphael de Paula Tito (2016). A comunidade LGBT no desdobramento da língua iorubá. Cadernos do CNLF: Sociolinguística, dialetologia e geografía lingüística 20(12): 9-21

Davis, Jenny L. (2014). "More than just 'gay Indians"': Intersecting articulations of twospirit gender, sexuality, and indigenousness. Zimman, Lal, Jenny L. Davis, and Joshua Raclaw, eds. Queer excursions: Retheorizing binaries in language, gender, and sexuality. New York, NY: Oxford University Press, 62-80

Debenport, Erin (2015). Fixing the Books: Secrecy, Literacy, and Perfectibility in Indigenous New Mexico. Santa Fe, NM: School for Advanced Research Press

Debenport, Erin (in press). What is secrecy and what is its relation to social facts? Vital Topics Forum: What Happened to Social Facts? American Anthropologist

Dyszak, A. S. (2016). The lexis of Polish sexual minorities slang. Philology: International scientific journal 5(5): 59-67 
Eribon, Didier (2004). Insult and the making of the gay self. Michael Lucey (trans). Durham, NC: Duke University Press

Fessler, Jeff, and Karen Rauch (1997). When drag is not a car race: An irreverent dictionary of over 400 gay and lesbian words and phrases. New York, NY: Simon and Schuster

Gilmore, Perry. (2015). Kisisi (our language): The story of Colin and Sadiki. Hoboken, NJ: Wiley-Blackwell

Gaudio, Rudolf P. (2014). Acting like women, acted upon: Gender and agency in Hausa sexual narratives. Lal Zimman, Jenny L. Davis, and Joshua Raclaw, eds. Queer excursions: Retheorizing binaries in language, gender, and sexuality. New York, NY: Oxford University Press, 170-194

Greening-Jackson, Tim (Sr. Matic de Bauchery) (trans.) (2015). The Polari Bible. Seventh Edition. Manchester, UK: Larlou Press

Griffith, Andy (1964). Andy and Cleopatra. Los Angeles, CA: Capital Records

Hagius, Hugh (eds) (2010). Swasarnt Nerf's Gay Guides for 1949. New York: Bibliogay

Hall, Kira (1997). “Go suck your husband's sugarcane!”: Hijras and the use of sexual insult. Livia, Anna, and Kira Hall, eds. Queerly phrased: Language, gender and sexuality. New York: Oxford University Press, 430-460

Hall, Kira. (2002). "Unnatural” gender in Hindi. Hellinger, Marlis, and Hadumod Bussman, eds. Gender across languages: The linguistic representation of women and men. Amsterdam: John Benjamins, 133-162

Hall, Kira. (2013). “It's a hijra!": Queer linguistics revisited. Discourse and Society 24(5): 634642. https://doi.org/10.1177/0957926513490321

Halperin, David M. (2007). What do gaymen want?: An essay on sex, risk, and subjectivity. Ann Arbor, MI: University of Michigan Press

Halperin, David M., and Valerie Traub (eds.) (2010). Gay Shame. Chicago, IL: University of Chicago Press

Harvey, Keith (2000). Describing camp talk: Language/pragmatics/politics. Language and Literature 9(3): 240-260. https://doi.org/10.1177/096394700000900303

Harvey, Keith (2002). Camp talk and citationality: A queer take on "authentic" and "represented" utterance. Journal of Pragmatics 34: 1145-1165. https://doi.org/10.1016/S0378-2166(01)00058-3

Hayes, Joseph J. (1981). Gayspeak. James W. Chesebro, ed. Gayspeak: Gay male and lesbian communication. New York: Pilgrim Press, 45-57

Heath, Jeff. (1984). Language contact and language change. Annual Review of Anthropology 113: 367-384

Hill, Jane H. (1993). Is it really "No Problemo"? Queen, Robin, and Rusty Barrett, eds. SALSA I: Proceedings of the First Annual Symposium about Language and Society-Austin. Texas Linguistic Forum 33:1-12

Hill, Jane H. (1998). Language, race and white public space. American Anthropologist 100: 680-89

Johnsen, Ole Ringdal (2008). “He’s a big old girl!”: Negotiation by gender inversion in gay men's speech. Journal of Homosexuality 54(1/2): 150-186.

https://doi.org/10.1080/00918360801952044 
Kontovas, Nicholas (2012). Lubunca: The historical development of Istanbul's queer slang and a social-functional approach to diachronic processes in language. M.A. Thesis, Department of Central Eurasian Studies. Indiana University

Kulick, Don (1998). Travesti: Sex, Gender, and Culture among Brazilian Transgendered Prostitutes. Chicago, IL: University of Chicago Press

Kyuchukov, Hristo, and Peter Bakker (1999). A note on Romani words in the gay slang of Istanbul. Grazer Linguistische Studien 51: 95-98

Legman, Gershon (1941). The language of homosexuality: An American glossary. In George Henry, ed. Sex variants: A study of homosexual patterns. New York: Hoeber

Levon, Erez (2010a). The voice of others: Identity, alterity and gender normativity among gay men in Israel. Queen Mary's OPAL \#18 Occasional Papers Advancing Linguistics

Levon, Erez (2010b). Language and the politics of sexuality: Lesbians and gays in Israel. London, UK: Palgrave Macmillan

Livia, Anna (2000). Pronoun envy: Literary uses of linguistic gender. New York, NY: Oxford University Press

Manalansan IV, Martin F. (2003). Global divas: Filipino gay men in the diaspora. Durham, NC: Duke University Press

Max, H. (1988). Gay(s)language: A dic(k)tionary of gay slang. Austin, TX: Banned Books

Montoliu, César (2005). Is Kaliardà, Greek gay slang, a mixed Gypsy language? Erytheia: Revista de estudios bizantinos y neogriegos 26: 299-318

Msibi, Thabo (2013). Homophobic language and linguistic resistance in KwaZulu-Natal, South Afica. In Atanga, Lillian L., Sibonile E. Ellece, Lia Litosseliti, and Jane Sunderland, eds. Gender and language in Sub-Saharan Africa. Amsterdam and Philadelphia: John Benjamins. 253-274

Myers-Scotton, Carol (1993). Dueling languages: Grammatical structure in codeswitching. New York, NY: Oxford University Press

Murray, Stephen O. (1978). The art of gay insulting. Anthropological Linguistics 21(5): 211223

Muysken, Pieter (2000). Bilingual Speech. Cambridge, U.K.: Cambridge University Press

Nemtsev, Mikhail (2007). The emergence of a sexual minorities movement in post-Soviet Russia. Budapest: MA Thesis, Department of Gender Studies, Central European University

Nerf, Swasarnt, Peter Asti, and Daphne Dilldock (1949). The Gay Girl's Guide: A Primer for Novices, a Review for Roués. San Francisco: Phallus Press

Ntuli, Praisegod Mduduzi (2009). IsiNgqumo: Exploring origins, growth, and sociolinguistics of an Nguni urban-township homosexual subculture. MA Thesis, Durban, South Africa: University of KwaZulu-Natal

Painter, Dorothy S. (1981). Recognition among lesbians in straight settings. James W. Chesebro, ed. Gayspeak: Gay Male and Lesbian Communication. New York: The Pilgrim Press, 68-79

Pascual, Gemma R. (2016). Sward speak (gay lingo) in the Philippine context: A morphological analysis. International Journal of Advanced Research in Management and Social Sciences 5(12): 32-36 
Peña, Susana (2004). Pájaration and transculturation: Language and meaning in Miami’s Cuban American gay worlds. William L. Leap ad Tom Boellstorff, eds. Speaking in queer tongues: Globalization and gay language. Urbana and Chicago, IL: University of Illinois Press, 231-250

Peterkin, Allan D. (2003). Outburst: A queer erotic thesaurus. Vancouver, BC: Arsenal Pulp Press

Peterson, Leighton C., and Anthony K. Webster (2013). Speech play and language ideologies in Navajo terminology development. Pragmatics 23(1): 93-116. https://doi.org/10.1075/prag.23.1.05pet

Prado, Emily (2017). Portland is burning: Local ballroom culture is about much more than looking fabulous. Portland Mercury. Published on Dec 6, 2017. Available at: https:// www.portlandmercury.com/feature/2017/12/06/19526329/portland-is-burning

Queen, Robin (1997). 'I don't speak Spritch': Locating lesbian language. Livia, Anna, and Kira Hall, eds. Queerly phrased: Language, gender and sexuality. New York: Oxford University Press. 233-256

Reuter, Donald F. (2006). Gay-2-Zee: A dictionary of sex, subtext, and the sublime. New York, NY: St. Martin's Griffin

Rodgers, Bruce (1972). The queen's vernacular: A gay lexicon. San Francisco: Straight Arrow Press

Rudwick, Stephanie (2010). "Gay and Zulu, we speak isiNgqumo": Ethnolinguistic identity constructions. Transformation 74: 112-134

Rudwick, Stephanie (2011). Defying a myth: A gay sub-culture in contemporary South Africa. Nordic Journal of African Studies 20(2): 90-111

Rudwick, Stephanie, and Mduduzi Ntuli (2008). IsiNgqumo - Introducing a gay Black South African linguistic variety. Southern African Linguistics and Applied Language Studies 26(4): 445-456. https://doi.org/10.2989/SALALS.2008.26.4.3.675

Rudwick, Stephanie, and Thabo Msibi (2016). Social and linguistic representations of South African same-sex relations: The case of skesana. Levon, Erez, and Ronald Beline Mendes, eds. Language, sexuality, and power: Studies in intersectional sociolinguistics. New York: Oxford University Press, 39-59

Sherzer, Joel (2002). Speech play and verbal art. Austin: University of Texas Press

Simmonds, John (producer) (1968). "Journey to Uranus" written by Barry Took, Brian Cooke, and Johnnie Mortimer. Round the Horne. BBC (radio)

Simons, Gary F. (2017). Ethnologue: Languages of the World. 20th edition. Dallas: SIL International

Sonenschein, David (1969). The homosexual's language. The Journal of Sex Research 5(4): 281-291

Summerbell, Richard (1985). ab·nor'mally HAPPY:Agay dictionary. Vancouver, BC: New Star Books

Twain, Mark (1903). The jumping frog: In English, Then in French, Then Clawed Back Into a Civilized Language Once More by Patient, Unremunerated Toil. New York, NY: Harper \& Brothers 
Ukolova, Iryna (2009). Specificities of the slang Habal'stvo in the discourse of Ukrainian homosexuals. Budapest: MA Thesis, Department of Gender Studies, Central European University

Yu, Alan (2008). On iterative infixation. Change, Charles B., and Hannah J Haynie, eds. Proceedings of the 26th West Coast Conference on Formal Linguistics. Sommerville, MA: Cascadilla Proceedings Profect, 516-524

Webster, Anthony K. (2010). On intimate grammars with examples from Navajo English, Navlish, and Navajo. Journal of Anthropological Research 66: 187-208. https://doi.org/10.3998/jar.0521004.0066.202

Webster, Anthony K. (2015). Intimate grammars: An ethnography of Navajo poetry. Tucson: University of Arizona Press

Zimman, Lal (2014). The discursive construction of sex: Remaking and reclaiming the gendered body in talk about genitals among trans men. Zimman, Lal, Jenny L. Davis, and Joshua Raclaw, eds. Queer excursions: Retheorizing binaries in language, gender, and sexuality. New York, NY: Oxford University Press, 12-34

\section{Govorna igra, rodna igra i verbalna umješnost u queer žargonima}

U radu je prikazana usporedna analiza žargona (ili tajnih varijeteta) koje upotrebljavaju govornici u zajednicama koje se identificiraju kao rodno ili seksualno nenormativne. Iz usporedbe devet žargona različitih jezika moguće je zaključiti da razvoj svakoga od njih uključuje bogatu govornu igru. U radu se analiziraju raznoliki uzorci govorne igre, primjerice međujezična igra, ludički varijeteti, morfološka reanaliza i inovacija te leksičke zamjene unutar lokalnoga jezika. Važnost govorne igre u promatranim zajednicama oprimjeruje se žanrom kvaziprijevoda u kojima se poznati tekstovi (poput Shakespearea ili Biblije) reproduciraju upotrebom žargona. Rezultati istraživanja ukazuju na to da su govorna igra i verbalna umješnost važni, ali nedovoljno istraženi elementi queer kultura.

Keywords: argot, speech play, verbal art, sexuality, gender, queer culture

Ključne riječi: argot, govorna igra, verbalna umješnost, seksualnost, rod, queer kultura 